\title{
The Influence of House Plants on Indoor $\mathrm{CO}_{2}$
}

\author{
Hakan Sevik ${ }^{1}$ Mehmet Cetin ${ }^{2 *}$, Kerim Guney ${ }^{3}$, Nur Belkayali² \\ ${ }^{1}$ Kastamonu University, Faculty of Engineering and Architecture, Department of Environmental Engineering, \\ 37150, Kastamonu, Turkey \\ ${ }^{2}$ Kastamonu University, Faculty of Engineering and Architecture, Department of Landscape Architecture, \\ 37150, Kastamonu, Turkey \\ ${ }^{3}$ Kastamonu University, Faculty of Forestry, Department of Forest Engineering, \\ 37150, Kastamonu, Turkey
}

Received: 13 December 2016

Accepted: 8 February 2017

\begin{abstract}
This study aimed at determining the effect of carbon dioxide $\left(\mathrm{CO}_{2}\right)$ in the internal environment of different indoor plants. Spathiphyllum (Spathiphyllum floribundum Schott), Yucca (Yucca elephantipes Regel), Dieffenbachia (Dieffenbachia amoena Gentil), and Ficus (Ficus benjamina L.) are frequently used in studies of indoor plants that examine light temperature depending on leaf surface and the effects of $\mathrm{CO}_{2}$ in the studied environment. As a result, decreases in $\mathrm{CO}_{2}$ were at the highest level in Ficus, and Dieffenbachia at $25^{\circ} \mathrm{C}$, followed by Spathiphyllum at $25^{\circ} \mathrm{C}$ and Yucca at $20^{\circ} \mathrm{C}$. The amount of photosynthesis increased the leaf surface. For this reason, they reduced the amount of $\mathrm{CO}_{2}$ by increasing the amount of photosynthesis. The plant leaf surface was standardized, and calculations were made to meet the objective and the amount of $\mathrm{CO}_{2}$ in the local environment. Based on these calculations, it was determined that the greatest reduction of $\mathrm{CO}_{2}$ comes from the Ficus plant. In conclusion, the same layer as the surface are $1 \mathrm{~m}^{2}$ leaf surface from Ficus benjamina on $1 \mathrm{~m}^{3}$ without air vent in which the amount of $\mathrm{CO}_{2}$ in one hour could be reduced to about the level from $2,000 \mathrm{ppm}$ at $25^{\circ} \mathrm{C} 480.74 \mathrm{ppm}$ and $408.08 \mathrm{ppm}$ at $20^{\circ} \mathrm{C}$.
\end{abstract}

Keywords: $\mathrm{CO}_{2}$, plant, indoor, air quality, indoor plants, leaf surface

\section{Introduction}

The recent rise in urbanization has led to increased population density, particularly in urban areas. Hence the number of people per unit area has increased. Nowadays, urban people spend at least $80 \%$ of their lives in indoor environments because of increased housing and changing life conditions [1-3].

Rapid urbanization and industrialization have placed more distance between people and nature each day.

\footnotetext{
*e-mail: mehmet.cetin@temple.edu
}

This situation disrupts the harmony that is expected to exist between people and their environment. Human beings, as part of nature, carry with them a part of nature wherever they live. This has sometimes been in the form of a houseplant, a small garden, or sometimes a delicately organized park [3-5].

Plants that exist particularly in indoor environments, where people spend more than $80 \%$ of their lives, undertake many ecological and aesthetical functions. Indoor plants reduce all kinds of air pollution [6], increase productivity [7], relieve people psychologically, and minimize stress and negative feelings [3]. Previous studies have reported that the presence of plants in indoor environments reduces diseases and absenteeism [3, 8]. 
One of the most important reasons plants are wanted in indoor environments is their influence on carbon dioxide $\left(\mathrm{CO}_{2}\right) \cdot \mathrm{CO}_{2}$ is one of the gases the composition of which changes in indoor environments in the fastest way as a result of human metabolic activities. The composition of air with $21 \%$ oxygen $\left(\mathrm{O}_{2}\right)$ and $0.033 \% \mathrm{CO}_{2}$ when inhaled from the normal atmosphere turns to have an $\mathrm{O}_{2}$ level of $16-17 \%$ and a $\mathrm{CO}_{2}$ level of $4 \%$ when exhaled from the lungs. This change leads to a rapid increase in $\mathrm{CO}_{2}$ amount, particularly in environments such as schools, malls, and hospitals, where people are collectively active [9]. When the rate of $\mathrm{CO}_{2}$ increases in an environment, this leads to fatigue, difficulty in perception, and sleepiness [10]. When the amount of $\mathrm{CO}_{2}$ exceeds $1,000 \mathrm{ppm}$, headache, vertigo, fatigue, concentration disorders, and smell disorders may be experienced. When it exceeds $1,500 \mathrm{ppm}$, it results in irritation in throat and nose, nasal flow, cough, and eye drainage [11]. This is particularly evident in indoor environments where the majority of daily life is spent. The reduction in indoor air quality influences people's performance and health [10].

According to the authorities, air quality can be regarded as harmless if $\mathrm{CO}_{2}$ levels are below 1,000 ppm, elevated if between 1,000 and 2,000 ppm, and hygienically unacceptable if above 2,000 ppm [12]. However, previous studies have shown that $\mathrm{CO}_{2}$ amounts have reached 4,000 ppm in schools [13] and 2,500 ppm in offices [14].

The most influential way to reduce $\mathrm{CO}_{2}$ in an environment is ventilation. Indeed, outdoor air can be 5 to 100 times as clear as indoor air [9]. However, even a short period of ventilation leads to a considerable loss of heat in the environment, particularly in winter months, leading to inadequate ventilation in indoor environments.

Another way to reduce $\mathrm{CO}_{2}$ in indoor environments is by using plants. Plants photosynthesize in environments where light and heat are adequate as part of their natural life process. They absorb the $\mathrm{CO}_{2}$ in the environment through their stomas for photosynthesis. Hence, they use $\mathrm{CO}_{2}$ for photosynthesis, leading to a reduction in its amount in the environment. However, plants are also living organisms and need certain conditions to survive. They also change environmental conditions through their metabolic activities. Plants emit oxygen and absorb $\mathrm{CO}_{2}$ when environmental conditions are suitable for their growth. When conditions change, the situation becomes reverse. This may result in negative influences on human health, particularly in indoor environments that are limited. Obviously, environmental conditions for each plant to survive change. Even when the conditions are optimal, plants may have different photosynthesis rates and thus have varying degrees of influence on indoor $\mathrm{CO}_{2}$ amounts. Therefore, plants can be effectively used to maintain healthy conditions regarding $\mathrm{CO}_{2}$ amounts in indoor environments where people spend most of their lives if one detects to what extent indoor conditions are suitable for plants, under which conditions the metabolic activities of plants influence indoor $\mathrm{CO}_{2}$ amounts, and what kind of influence they have.
The purpose of this study is to reveal the influence of certain plant species that can be used as indoor plants on indoor $\mathrm{CO}_{2}$ amounts. The study focuses on the changes made by plants on $\mathrm{CO}_{2}$ amounts at various temperature levels. To this end, four different indoor plants were selected to determine how they change indoor $\mathrm{CO}_{2}$ amounts at five different leaf surfaces, five different temperature levels, and under 20,000 lux light and dark conditions.

\section{Material and Methods}

This study focuses on the influence of certain frequently used indoor ornamental plants on $\mathrm{CO}_{2}$ amounts in indoor environments. In this sense, Spathiphyllum (Spathiphyllum floribundum Schott), Yucca (Yucca elephantipes Regel), Dieffenbachia (Dieffenbachia amoena Gentil), and Ficus (Ficus benjamina L.), which are common indoor plants, constitute the study material. These plants differ from one another in terms of ecological demands and physical characteristics (e.g., leaf area and body shape).

The study was conducted in a plant growth chamber that was not in contact with outdoor air and whose internal volume was known. The light and temperature conditions of the chamber were determined independent of the outdoor environment. In addition to the plant, a measurement device that can regularly measure $\mathrm{CO}_{2}$, temperature, and humidity and transfer measurements to the computer was placed in the plant growth chamber.

Particular attention was paid to plants' being healthy, having a proper root/body ratio, and not being exposed to any stress factor. Therefore, the pots of the procured plants were changed in the first place so that root/body ratio could be increased in favor of the roots.

The plant growth chamber in which the study conditions were provided was of the Jaiotech GC 300 brand. This plant growth chamber produces 20,000 lux light when all the lights are turned on, and its temperature can be set with a precision of $1^{\circ} \mathrm{C}$ (equipped with a heating and cooling system). It also has a $\mathrm{CO}_{2}$ tank to increase environmental $\mathrm{CO}_{2}$. It can periodically be programmed to maintain the required conditions.

Given that the study was based on absolute tightness, a glass chamber whose air tightness had been tested was placed inside the chamber. An Extech desktop indoor air quality $\mathrm{CO}_{2}$ data logger was placed inside this glass chamber. This device is used for $\mathrm{CO}_{2}$ measurements and is capable of measuring at $1 \mathrm{ppm}$ precision. This $\mathrm{CO}_{2}$ meter was calibrated prior to being used. It was also tested for its $\mathrm{CO}_{2}$ tightness, and it was ensured that there would be no air intake or outlet.

The plants were placed inside the chamber for measurements. The $\mathrm{CO}_{2}$ amount inside the chamber was set to $2,000 \mathrm{ppm} \pm 10 \%$. The initial $\mathrm{CO}_{2}$ amount was set to be $2,000 \mathrm{ppm}$ because plants generally reach maximum photosynthesis speed at levels higher than 1,200-1,300 ppm. Furthermore, previous studies on 
indoor air quality have demonstrated that indoor $\mathrm{CO}_{2}$ amount reaches 2,000 ppm in environments where people are collectively active in a short period [15-16].

Raising the $\mathrm{CO}_{2}$ amount to $2,000 \mathrm{ppm} \pm 200 \mathrm{ppm}$ level was performed through respiration into the device for a few minutes. The $\mathrm{CO}_{2}$ amount in the air exhaled was around 40,000 ppm following human respiration. Therefore, respiring in the chamber where the plant was placed increased the $\mathrm{CO}_{2}$ amount to the required level in a short period. However, the $\mathrm{CO}_{2}$ amount became homogenized and stable in the air after a while. Therefore, at least 10 minutes passed before the chamber was closed. When the $\mathrm{CO}_{2}$ amount reached the required level, the chamber was closed with an absolute tightness. Meanwhile, when the $\mathrm{CO}_{2}$ amount was higher than required, the chamber was ventilated; and when it was lower than required, respiration was repeated to obtain the required $\mathrm{CO}_{2}$ amount.

This study seeks to reveal the influences of plants on $\mathrm{CO}_{2}$ amount in illuminated and dark environments. The selected amount of light was 20,000 lux.

The plants that were prepared for the measurements were placed inside the chamber. The measurement order of the chamber is as follows:

$-15^{\circ} \mathrm{C}$ degrees, 20,000 lux light, 12 hours

- $15^{\circ} \mathrm{C}$ degrees, dark environment, 12 hours

- $20^{\circ} \mathrm{C}$ degrees, 20,000 lux light, 12 hours

- $20^{\circ} \mathrm{C}$ degrees, dark environment, 12 hours

- $25^{\circ} \mathrm{C}$ degrees, 20,000 lux light, 12 hours

- $25^{\circ} \mathrm{C}$ degrees, dark environment, 12 hours

- $30^{\circ} \mathrm{C}$ degrees, 20,000 lux light, 12 hours

- $30^{\circ} \mathrm{C}$ degrees, dark environment, 12 hours

- $35^{\circ} \mathrm{C}$ degrees, 20,000 lux light, 12 hours

- $35^{\circ} \mathrm{C}$ degrees, dark environment, 12 hours

Keeping the plants in the light for 12 hours and in the dark for 12 hours is about simulating the environment that plants are used to as much as possible. Plants stay in the light and stay in the dark for a certain period every day. The measurements were planned in this manner to avoid disturbing the order the plants were used to. The device was set as explained above. The plant was then placed inside the chamber within the device. The measurement device inside the same environment as the plant was started in such a way that it would measure every five minutes and record the data, and the chamber was closed tightly.

The data were transferred to the computer after the measurement ended. The net volume of the chamber was calculated (by subtracting the volume of the pot and the body volumes of Yucca, Ficus, and Dieffenbachia from the volume of the chamber).

The purpose was to show the performances of the plants at the end of an hour. However, considering that the measurement device would be stable only after a while and the time it would take for the plants to get used to the values in the environment they were put in, the plants were placed inside the chamber at least one hour before starting the measurement. Hence, the measurement results that were obtained at least one hour after the plants were placed were considered for a sound measurement. Each plant remained inside the chamber for five days after being placed in it. The device was operated in that period with the settings specified above. The $\mathrm{CO}_{2}$ measurement device performed measurements every five minutes. Afterward, the data were transferred to the computer for assessment.

As data evaluation dealt with the plant performances at the end of an hour and the values obtained at least one hour after the placement of the plants inside the chamber were considered for a sound measurement, the measurements that were performed while the chamber was making transitions between the programs were also ignored. For instance, while the climate chamber was transiting from the program of 12 hours in the dark with $20^{\circ} \mathrm{C}$ to the program of 12 hours in the light with $25^{\circ} \mathrm{C}$, plant performance was ignored for one hour. The values obtained at the end of this process were considered. Hence, 10 measurements were carried out with each one lasting one hour through a device that operated for 12 hours. The data were obtained by calculating the difference between the initial $\mathrm{CO}_{2}$ values and the values at the end of one hour.

This study aimed to reveal the influences of five different leaf surfaces on $\mathrm{CO}_{2}$ amount. Therefore, after performing the initial measurements, approximately $1 / 5$ of the plant leaves were cut to calculate the leaf area. In the next period, $1 / 4$ of the leaf area was cut, followed by $1 / 3$ and $1 / 2$, so that nearly $1 / 5$ of the initial leaf area was cut in each period. However, leaf cutting was performed based on estimations, and the leaf area was calculated after being cut.

After obtaining the data, they were standardized to determine which leaf surface had the most influence on $1 \mathrm{~m}^{3}$ of air as well as the degree of such influence. The plant growth chamber's capacity is $70 \times 70 \times 110 \mathrm{~cm}$. The total of volume is $0.539 \mathrm{~m}^{3}$. For instance, assuming that in a chamber with a volume of $0.486 \mathrm{~m}^{3}$ (after subtracting the volume of the pot), Ficus having $0.245 \mathrm{~m}^{2}$ leaf area reduced $\mathrm{CO}_{2}$ by $157 \mathrm{ppm}$ in an hour. While assessing these data, a calculation was made based on the equation that the $\mathrm{CO}_{2}$ amount in an area of $1 \mathrm{~m}^{3}$ is reduced by $157 \mathrm{ppm}$ by Ficus having $\mathrm{x} \mathrm{m}^{2}$ leaf area assuming that Ficus having $0.245 \mathrm{~m}^{2}$ leaf area reduced the $\mathrm{CO}_{2}$ amount by $157 \mathrm{ppm}$ in an area of $0.486 \mathrm{~m}^{3}$. Hence, it was recorded as follows: "Ficus having a leaf area of $0.504 \mathrm{~m}^{2}$ reduces the $\mathrm{CO}_{2}$ amount in an area of $1 \mathrm{~m}^{3}$ by $157 \mathrm{ppm}$ in one hour." This means the differences that stemmed from the pot sizes were eliminated.

While calculating the net volume of the chamber, only the volumes of Yucca, Ficus, and Dieffenbachia were considered because their body volumes could be calculated. The volumes of the leaves were ignored. The measurements indicated that leaf thickness did not even reach $2 \mathrm{~mm}$ in any of the studied species. When the leaf volume is calculated, for instance, assuming that Ficus having a leaf area of $0.245 \mathrm{~m}^{2}$ has a leaf thickness of $2 \mathrm{~mm}$ (the leaf thickness of Ficus is lower than $1 \mathrm{~mm}$ ), the leaf volume calculated will be $0.245 \mathrm{~m}^{2 *}$ $0.002 \mathrm{~m}=0.00049 \mathrm{~m}^{3}$. In a chamber having a net volume 
of $0.486 \mathrm{~m}^{3}$ (after subtracting the volumes of the pot and the plant body), a leaf volume of $0.00049 \mathrm{~m}^{3}$ corresponds to nearly $1 / 1000$ of the chamber volume. The study considered that ignoring the leaf volume would not affect the results as leaf volume, when roughly calculated, did not even reach $1 / 1000$ of the total chamber volume. As a result, leaf volume was ignored.

Hence, measurements of the study were performed in 200 combinations involving:

- Four different species (Spathiphyllum, Yucca,
- Two different light conditions (20,000 lux light and dark).

- Five different degrees of temperature $(15,20,25,30$, and $35^{\circ} \mathrm{C}$ ).

- Five leaf surfaces.

Each measurement was repeated at least 10 times. Thus an attempt was made to ensure that measurement would be performed for 2,000 hours total. However, the measurements were performed for 1,990 hours because performing measurements with Spathiphyllum in the dark at $35^{\circ} \mathrm{C}$ was not possible.

Table 1. Effect of $\mathrm{CO}_{2}$ amount by the plants having different leaf surfaces under 20,000 lux light depending on temperature.

\begin{tabular}{|c|c|c|c|c|c|c|c|c|}
\hline & \multicolumn{8}{|c|}{20,000 lux light on species } \\
\hline & \multicolumn{2}{|c|}{ Ficus } & \multicolumn{2}{|c|}{ Dieffenbachia } & \multicolumn{2}{|c|}{ Spathiphyllum } & \multicolumn{2}{|c|}{ Yucca } \\
\hline Temperature & $\begin{array}{c}\text { Leaf } \\
\text { Surface } \\
\left(\mathrm{m}^{2}\right)\end{array}$ & $\begin{array}{c}\text { Average* } \\
\text { (reduction of } \\
\mathrm{CO}_{2} \text { per hour) }\end{array}$ & $\begin{array}{c}\text { Leaf } \\
\text { Surface } \\
\left(\mathrm{m}^{2}\right)\end{array}$ & $\begin{array}{c}\text { Average* } \\
\text { (reduction of } \\
\mathrm{CO}_{2} \text { per hour) }\end{array}$ & $\begin{array}{l}\text { Leaf } \\
\text { Surface } \\
\left(\mathrm{m}^{2}\right)\end{array}$ & $\begin{array}{c}\text { Average* } \\
\text { (reduction of } \\
\mathrm{CO}_{2} \text { per hour) }\end{array}$ & $\begin{array}{c}\text { Leaf } \\
\text { Surface } \\
\left(\mathrm{m}^{2}\right)\end{array}$ & $\begin{array}{c}\text { Average* } \\
\text { (reduction of } \\
\mathrm{CO}_{2} \text { per hour) }\end{array}$ \\
\hline \multirow{5}{*}{$15^{\circ} \mathrm{C}$} & 0.185 & -7.8 & 0.192 & -6 & 0.336 & -9.8 & 0.1395 & -1.2 \\
\hline & 0.403 & -15.2 & 0.384 & -10.5 & 0.426 & -15.9 & 0.298 & -1.6 \\
\hline & 0.514 & -21.1 & 0.469 & -12.5 & 0.516 & -13.8 & 0.509 & -3.5 \\
\hline & 0.726 & -28.9 & 0.628 & -16.3 & 0.712 & -20.9 & 0.745 & -3.8 \\
\hline & 0.806 & -40.2 & 0.747 & -25.6 & 1.038 & -40 & 0.837 & -6 \\
\hline \multirow{5}{*}{$20^{\circ} \mathrm{C}$} & 0.185 & -75.9 & 0.192 & -56.8 & 0.336 & -75.9 & 0.1395 & -22 \\
\hline & 0.403 & -163.4 & 0.384 & -109.3 & 0.426 & -110.3 & 0.298 & -56.7 \\
\hline & 0.514 & -212.4 & 0.469 & -116.3 & 0.516 & -112.6 & 0.509 & -71.7 \\
\hline & 0.726 & -299.9 & 0.628 & -179.3 & 0.712 & -129.3 & 0.745 & -154.8 \\
\hline & 0.806 & -321 & 0.747 & -187.9 & 1.038 & -228.7 & 0.837 & -120 \\
\hline \multirow{5}{*}{$25^{\circ} \mathrm{C}$} & 0.185 & -87.8 & 0.192 & -61.6 & 0.336 & -146.9 & 0.1395 & -15.5 \\
\hline & 0.403 & -192.9 & 0.384 & -125.6 & 0.426 & -191.2 & 0.298 & -33.2 \\
\hline & 0.514 & -250.1 & 0.469 & -152.5 & 0.516 & -193.3 & 0.509 & -38.9 \\
\hline & 0.726 & -332.5 & 0.628 & -197.3 & 0.712 & -254.1 & 0.745 & -74 \\
\hline & 0.806 & -407.6 & 0.747 & -216.5 & 1.038 & -361.2 & 0.837 & -61 \\
\hline \multirow{5}{*}{$30^{\circ} \mathrm{C}$} & 0.185 & -43.7 & 0.192 & -15.5 & 0.336 & -54.6 & 0.1395 & -7.1 \\
\hline & 0.403 & -94.6 & 0.384 & -31.6 & 0.426 & -54.5 & 0.298 & -15.5 \\
\hline & 0.514 & -132.8 & 0.469 & -40.3 & 0.516 & -55.3 & 0.509 & -24.2 \\
\hline & 0.726 & -183.8 & 0.628 & -48.6 & 0.712 & -62.5 & 0.745 & -37.8 \\
\hline & 0.806 & -197.5 & 0.747 & -58.3 & 1.038 & -139.1 & 0.837 & -46.2 \\
\hline \multirow{5}{*}{$35^{\circ} \mathrm{C}$} & 0.185 & -40 & 0.192 & 0.7 & 0.336 & -2.9 & 0.1395 & -3.3 \\
\hline & 0.403 & -87.4 & 0.384 & 1.5 & 0.426 & -7 & 0.298 & -6.8 \\
\hline & 0.514 & -112.8 & 0.469 & 3.1 & 0.516 & -7.6 & 0.509 & -11.1 \\
\hline & 0.726 & -157.4 & 0.628 & 3.6 & 0.712 & -5.2 & 0.745 & -17.7 \\
\hline & 0.806 & -172.4 & 0.747 & 3.3 & 1.038 & -5.6 & 0.837 & -17.1 \\
\hline
\end{tabular}

*Mean average is reduction of $\mathrm{CO}_{2}$ per hour 
Table 2. Influences of the species on $\mathrm{CO}_{2}$ amount under 20,000 lux light depending on temperature.

\begin{tabular}{|c|c|c|c|c|c|}
\hline \multirow{2}{*}{ Species } & \multicolumn{5}{|c|}{ Temperature } \\
\cline { 2 - 6 } & $15^{\circ} \mathrm{C}$ & $20^{\circ} \mathrm{C}$ & $25^{\circ} \mathrm{C}$ & $30^{\circ} \mathrm{C}$ & $35^{\circ} \mathrm{C}$ \\
\hline Ficus & -42.08 & -408.08 & -480.74 & -245.52 & -216.68 \\
\hline Dieffenbachia & -29.09 & -273.10 & -315.41 & -80.88 & 4.86 \\
\hline Spathiphyllum & -32.26 & -220.92 & -393.12 & -123.78 & -10.52 \\
\hline Yucca & -6.28 & -167.54 & -93.74 & -50.96 & -22.42 \\
\hline
\end{tabular}

\section{Results and Discussion}

In the end, the extent to which the $\mathrm{CO}_{2}$ amount was reduced by the plants having different leaf surfaces under 20,000 lux light was dependent on the temperature. The results are shown in Table 1.

The values in Table 1 show how many ppm the plants having the specified leaf surfaces reduced the $\mathrm{CO}_{2}$ amount in one hour from nearly 2,000 ppm under 20,000 lux light condition. In the experiments conducted under 20,000 lux, all the species excluding Dieffenbachia reduced the $\mathrm{CO}_{2}$ amount at all temperature levels. However, Dieffenbachia increased the $\mathrm{CO}_{2}$ amount in the environment at $35^{\circ} \mathrm{C}$. In addition, deformations were observed in the leaves at this temperature. The plant that had the highest influence on $\mathrm{CO}_{2}$ amount in the environment was Ficus, having a leaf surface of $0.806 \mathrm{~m}^{2}$. It reduced the $\mathrm{CO}_{2}$ amount in the environment by $-407.6 \mathrm{ppm}$ at $25^{\circ} \mathrm{C}$ and by $-321 \mathrm{ppm}$ at $20^{\circ} \mathrm{C}$. However, the values in the table indicate that the difference between the leaf surfaces could be deceptive. Hence, the data were standardized. The influence of each plant having a leaf surface of $1 \mathrm{~m}^{2}$ on the $\mathrm{CO}_{2}$ amount in the environment was calculated. The relevant results are shown in Table 2.

The values in Table 2 show that only Dieffenbachia increased the $\mathrm{CO}_{2}$ amount at $35^{\circ} \mathrm{C}$. All the other species reduced the $\mathrm{CO}_{2}$ amount in the illuminated environment at all temperature levels. However, the amount of reduction significantly varied from species to species. Of the species having $1 \mathrm{~m}^{2}$ leaf surface, the one that reduced $\mathrm{CO}_{2}$ most in $1 \mathrm{~m}^{3}$ of air was Ficus (by $480.74 \mathrm{ppm}$ ). This reduction occurred at $25^{\circ} \mathrm{C}$. The next biggest reduction was observed again with Ficus at $20^{\circ} \mathrm{C}$ (by 408.08 ppm). The highest reduction occurred at $25^{\circ} \mathrm{C}$ for all the species, excluding Yucca. The highest reduction was observed at $20^{\circ} \mathrm{C}$ for Yucca.

Calculations were made to reveal to what extent the $\mathrm{CO}_{2}$ amount was raised in the dark by the plants having different leaf surfaces depending on temperature. The relevant results are shown in Table 3.

The results in Table 3 show that all the species increased the $\mathrm{CO}_{2}$ amount in the environment at all temperature levels. However, Dieffenbachia underwent a deformation in its leaves at $35^{\circ} \mathrm{C}$. The values in Table 3 indicate that the plant that increased the $\mathrm{CO}_{2}$ amount in the environment at the highest level was Spathiphyllum at $25^{\circ} \mathrm{C}$. Spathiphyllum, having a leaf surface of $1.038 \mathrm{~m}^{2}$, increased the $\mathrm{CO}_{2}$ amount by $122.5 \mathrm{ppm}$ in one hour. Ficus, having a leaf surface of $0.806 \mathrm{~m}^{2}$, increased the $\mathrm{CO}_{2}$ amount in the environment by $87.8 \mathrm{ppm}$ in one hour at $35^{\circ} \mathrm{C}$. To make a clearer comparison between the species, we calculated how much the plants having $1 \mathrm{~m}^{2}$ leaf surface increased the $\mathrm{CO}_{2}$ amount at different temperature levels in the dark. The relevant results are presented in Table 4.

The values in Table 4 show that the $\mathrm{CO}_{2}$ amount increased at all temperature levels. This, indeed, is a quite natural result. Plants photosynthesize only in the illuminated environments and can reduce $\mathrm{CO}_{2}$ there. In the dark, however, they perform respiration and increase the $\mathrm{CO}_{2}$ amount in the environment. The analyses indicated that the plant that caused the highest increase in $\mathrm{CO}_{2}$ was Spathiphyllum at $25^{\circ} \mathrm{C}$. Spathiphyllum and its $1 \mathrm{~m}^{2}$ leaf surface increased the $\mathrm{CO}_{2}$ amount in $1 \mathrm{~m}^{3}$ air by $129.62 \mathrm{ppm}$ in one hour. The second highest increase was caused by Ficus at $35^{\circ} \mathrm{C}$. Given that Spathiphyllum was damaged at $35^{\circ} \mathrm{C}$ in the illuminated environment, its influence on the $\mathrm{CO}_{2}$ amount at $35^{\circ} \mathrm{C}$ in the dark could not be calculated.

The results show that plants change indoor $\mathrm{CO}_{2}$ amounts differently in the illuminated environment. In general, the influence of plants on $\mathrm{CO}_{2}$ amount increases depending on temperature. It reaches a peak at a certain level and then starts to decrease because of increasing temperature. In other words, it makes a bell-shaped curve. Kacar et al. [17] stated that the influence of temperature on photosynthesis in plant leaves generally makes a curve. Speed of photosynthesis increases with the temperature until a certain level, whereas photosynthesis rapidly decreases after a certain temperature. This is reported by many researchers [18].

However, the temperature level required for the highest speed of photosynthesis changes from (plant) species to species. According to Akman and Güney [19], usually $20-35^{\circ} \mathrm{C}$ are optimum values for photosynthesis, and the positive influence of temperature on photosynthesis can continue until $30^{\circ} \mathrm{C}$. This is consistent with the results of the present study. Indeed, increasing temperature raised the influence of the plants on the $\mathrm{CO}_{2}$ amount, and the influence of the plants on the $\mathrm{CO}_{2}$ amount started to decrease after $25^{\circ} \mathrm{C}$ for Ficus, Dieffenbachia, and Spathiphyllum, and after $20^{\circ} \mathrm{C}$ for Yucca. At $35^{\circ} \mathrm{C}$, Ficus showed a considerable influence on the $\mathrm{CO}_{2}$ amount, whereas Spathiphyllum and Yucca showed a limited influence. Meanwhile, Dieffenbachia started respiration at $35^{\circ} \mathrm{C}$.

In the present study, all the plants photosynthesized even at $15^{\circ} \mathrm{C}$. In general, the period of vegetation is considered to cover the days when temperature is not less than $10^{\circ} \mathrm{C}[20]$. Akman and Güney [19] reported that some conifers continue to photosynthesize even at $-30^{\circ} \mathrm{C}$ in temperate regions of the world.

Light is possibly the most important factor that determines the influence of plants on indoor $\mathrm{CO}_{2}$ amount. Some studies have attempted to determine how plants 
Table 3. Influences of the species on $\mathrm{CO}_{2}$ amount in the dark depending on leaf surface and temperature.

\begin{tabular}{|c|c|c|c|c|c|c|c|c|}
\hline \multirow[b]{3}{*}{ Temperature } & \multicolumn{8}{|c|}{ in the dark } \\
\hline & \multicolumn{2}{|c|}{ Ficus } & \multicolumn{2}{|c|}{ Dieffenbachia } & \multicolumn{2}{|c|}{ Spathiphyllum } & \multicolumn{2}{|c|}{ Yисса } \\
\hline & $\begin{array}{c}\text { Leaf } \\
\text { Surface } \\
\left(\mathrm{m}^{2}\right)\end{array}$ & $\begin{array}{c}\text { Average* } \\
\text { (reduction of } \\
\mathrm{CO}_{2} \text { per hour) }\end{array}$ & $\begin{array}{c}\text { Leaf } \\
\text { Surface } \\
\left(\mathrm{m}^{2}\right)\end{array}$ & $\begin{array}{c}\text { Average* } \\
\text { (reduction of } \\
\mathrm{CO}_{2} \text { per hour) }\end{array}$ & $\begin{array}{c}\text { Leaf } \\
\text { Surface } \\
\left(\mathrm{m}^{2}\right)\end{array}$ & $\begin{array}{c}\text { Average* } \\
\text { (reduction of } \\
\mathrm{CO}_{2} \text { per hour) }\end{array}$ & $\begin{array}{c}\text { Leaf } \\
\text { Surface } \\
\left(\mathrm{m}^{2}\right)\end{array}$ & $\begin{array}{c}\text { Average* } \\
\text { (reduction of } \\
\mathrm{CO}_{2} \text { per hour) }\end{array}$ \\
\hline \multirow{5}{*}{$15^{\circ} \mathrm{C}$} & 0.185 & 7 & 0.192 & 0.7 & 0.336 & 12.4 & 0.1395 & 2.4 \\
\hline & 0.403 & 15.3 & 0.384 & 3.3 & 0.426 & 28.2 & 0.298 & 5.8 \\
\hline & 0.514 & 20.8 & 0.469 & 4.5 & 0.516 & 31.7 & 0.509 & 9 \\
\hline & 0.726 & 27.6 & 0.628 & 4.1 & 0.712 & 44 & 0.745 & 15.9 \\
\hline & 0.806 & 31.5 & 0.747 & 5.1 & 1.038 & 63.6 & 0.837 & 14 \\
\hline \multirow{5}{*}{$20^{\circ} \mathrm{C}$} & 0.185 & 8.4 & 0.192 & 2.7 & 0.336 & 24.3 & 0.1395 & 5.1 \\
\hline & 0.403 & 18.3 & 0.384 & 6.8 & 0.426 & 26.9 & 0.298 & 10.4 \\
\hline & 0.514 & 25.4 & 0.469 & 7.9 & 0.516 & 39.7 & 0.509 & 18.4 \\
\hline & 0.726 & 35 & 0.628 & 10.4 & 0.712 & 45.7 & 0.745 & 26 \\
\hline & 0.806 & 40.6 & 0.747 & 10.8 & 1.038 & 78.9 & 0.837 & 31 \\
\hline \multirow{5}{*}{$25^{\circ} \mathrm{C}$} & 0.185 & 6.2 & 0.192 & 1.8 & 0.336 & 54 & 0.1395 & 7.3 \\
\hline & 0.403 & 12.7 & 0.384 & 2.9 & 0.426 & 64.3 & 0.298 & 15.4 \\
\hline & 0.514 & 14.1 & 0.469 & 3.8 & 0.516 & 63.5 & 0.509 & 22.9 \\
\hline & 0.726 & 21.5 & 0.628 & 5.1 & 0.712 & 67.5 & 0.745 & 40.6 \\
\hline & 0.806 & 34.1 & 0.747 & 8 & 1.038 & 122.5 & 0.837 & 41.1 \\
\hline \multirow{5}{*}{$30^{\circ} \mathrm{C}$} & 0.185 & 11.1 & 0.192 & 2.9 & 0.336 & 22.3 & 0.1395 & 4 \\
\hline & 0.403 & 23.3 & 0.384 & 4.4 & 0.426 & 30.6 & 0.298 & 9.7 \\
\hline & 0.514 & 31.8 & 0.469 & 4.3 & 0.516 & 31.4 & 0.509 & 15 \\
\hline & 0.726 & 43.4 & 0.628 & 6.7 & 0.712 & 41.7 & 0.745 & 27.6 \\
\hline & 0.806 & 46.4 & 0.747 & 7.5 & 1.038 & 70.6 & 0.837 & 22.8 \\
\hline \multirow{5}{*}{$35^{\circ} \mathrm{C}$} & 0.185 & 18.7 & 0.192 & 2.1 & & & 0.1395 & 1.9 \\
\hline & 0.403 & 40.9 & 0.384 & 2.9 & & & 0.298 & 4.4 \\
\hline & 0.514 & 51.7 & 0.469 & 2.9 & & & 0.509 & 11.2 \\
\hline & 0.726 & 70.8 & 0.628 & 4.7 & & & 0.745 & 14 \\
\hline & 0.806 & 87.8 & 0.747 & 6 & & & 0.837 & 16.3 \\
\hline
\end{tabular}

*Mean average is reduction of $\mathrm{CO}_{2}$ per hour

influence the $\mathrm{CO}_{2}$ amount in controlled environments. Cetin and Sevik [5] conducted a study regarding the reduction in $\mathrm{CO}_{2}$ amount in an area of $0.5 \mathrm{~m}^{3}$. During the day, Ficus elastica reduced $\mathrm{CO}_{2}$ by 2,216 ppm, Yucca massengena by 2,578 ppm, Ocimum basilicum by 401 ppm, Sinningia speciosa by $725 \mathrm{ppm}$, and Codia eumvariegatum by 790 ppm. During the night, on the other hand, Ficus elastica increased the $\mathrm{CO}_{2}$ amount in the environment by 351 ppm, Yucca massengena by 310 ppm, Ocimum basilicum by 11 ppm, Sinningia speciosa by 218 ppm, and Codiaeum variegatum by 84 ppm.

In another study, Sevik et al. [16] determined that during the day Schefflera arboricola reduced the $\mathrm{CO}_{2}$ amount in a $0.5 \mathrm{~m}^{3}$ area by $1,252 \mathrm{ppm}$, whereas Fuchsia magellanica reduced it by $252 \mathrm{ppm}$. Significant differences were observed between the plants in terms of the ratio of the $\mathrm{CO}_{2}$ amount consumed through photosynthesis to the $\mathrm{CO}_{2}$ amount produced through respiration (e.g., the ratio being over 3.5 in Schefflera arboricola and less than 2 in Fuchsia magellanica).

The results of the present study show that Yucca is one of the plants that requires direct sunlight, and Dieffenbachia and Spathiphyllum are ornamental plants that seek half-shadow conditions [16]. In the research conducted on Raphanussativus L. var. Saxa under highand low-light conditions, Lichtenthaler (1979) grew plants 
Table 4. Influences of the species on $\mathrm{CO}_{2}$ amount in the dark, depending on temperature.

\begin{tabular}{|c|c|c|c|c|c|}
\hline Species & \multicolumn{5}{|c|}{ Temperature } \\
\hline & $15^{\circ} \mathrm{C}$ & $20^{\circ} \mathrm{C}$ & $25^{\circ} \mathrm{C}$ & $30^{\circ} \mathrm{C}$ & $35^{\circ} \mathrm{C}$ \\
\hline Ficus & 38.64 & 47.76 & 32.82 & 59.50 & 101.92 \\
\hline Dieffenbachia & 7.04 & 15.93 & 8.77 & 11.29 & 8.04 \\
\hline Spathiphyllum & 57.56 & 70.58 & 129.62 & 65.14 & - \\
\hline Yucca & 18.16 & 35.62 & 50.08 & 30.70 & 17.38 \\
\hline
\end{tabular}

under 20,000-24,000 lux as a high-light condition. Studies show that plants like Heliamphora and Sarracenia require 25,000 lux 12 to 16 hours a day [16].

Given this information, 20,000 lux was considered to provide natural growth conditions for the plants. However, light is a comprehensive issue, and quality, quantity, and duration of light, besides its intensity, are important and influential in photosynthesis [21]. Hence, future research should focus on these aspects separately in detail.

In the present study, all the plants increased their $\mathrm{CO}_{2}$ amounts in the dark. In other words, they respired in the dark environment. This result is known and is mentioned in many studies [19, 22-23].

Another important result involves the ratio of the $\mathrm{CO}_{2}$ amount exhaled to the environment through respiration to the $\mathrm{CO}_{2}$ amount inhaled from the environment through photosynthesis during the day. At the optimum temperatures for the plants, the $\mathrm{CO}_{2}$ amount obtained by the plants from the environment in the presence of light was considerably higher than the $\mathrm{CO}_{2}$ amount they emitted to the environment through respiration in the dark. For example, at $25^{\circ} \mathrm{C}$, Dieffenbachia consumed $315.41 \mathrm{ppm} \mathrm{CO}_{2}$ in the light environment in one hour. However, at the same temperature level it produced only $8.77 \mathrm{ppm} \mathrm{CO}_{2}$ in the dark environment. That is, the $\mathrm{CO}_{2}$ amount it consumed under 20,000 lux light conditions in one hour was 36 times as much as the $\mathrm{CO}_{2}$ amount it produced in the dark at the same temperature. Therefore, plants can have a significant positive effect on indoor $\mathrm{CO}_{2}$ amount in summer months when sunlight is received for a long time and temperature is high.

The plants used in the study were selected from among the most frequently used indoor plants. If research is diversified and different factors are included, considerably more effective and important results can be obtained in this matter. For example, leaf structure must be included in future research. Kacar et al. [15] reported that some plant leaves are thick and enjoy the light less. When selecting the intensity of light, the fact that optimum quantity of light is different for every plant must be considered, and plants of light and plants of shadow should not be evaluated under the same light conditions. Indeed, Kacar et al. [15] stated that the ratio of quantity of light needed for the highest amount of photosynthesis is 8:1 for plants of sun and plants of shadow. This shows how important choice of light is for maximum photosynthesis speed.
Plants are living organisms. They need certain conditions to survive. In addition, they change the conditions of the environment they are in through their metabolic activities. When the conditions in the environment are suitable for plant development, they emit oxygen to the environment and absorb $\mathrm{CO}_{2}$ from the environment, but the opposite happens when conditions change [10]. This condition influences the $\mathrm{CO}_{2}$ amount in the environment as well. A study on this subject concluded that the $\mathrm{CO}_{2}$ amount in forestland averages around $391 \mathrm{ppm}$ during the daytime and around $422 \mathrm{ppm}$ during the nighttime in winter months, and around $148 \mathrm{ppm}$ during the daytime and $229 \mathrm{ppm}$ during the nighttime in summer months [24].

Many studies have shown that indoor ornamental plants can be used to reduce various indoor pollutants [25-26]. Torpy et al. [27] explored the potentials of Aglaonemacommutatum, Aspidistra elatior, Castanospermumaustrale, Chamaedoreaelegans, Dracaena deremensis compacta, Dypsislutescens, Ficus benjamina, and Howeaforsterianato in reducing indoor $\mathrm{CO}_{2}$ and found that the reducing effects of plants vary depending on light conditions. Plants have a great variety of reducing effects depending on light conditions. In this study, the plants were first kept in high- or low-light conditions for 93 days, thereby accustoming them to the relevant quantity of light. The $\mathrm{CO}_{2}$ amount that was reduced

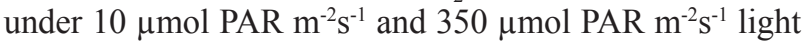
conditions was then determined. Then how much they reduced the $\mathrm{CO}_{2}$ amount under $10 \mu \mathrm{mol}$ PAR $\mathrm{m}^{-2} \mathrm{~s}^{-1}$ and

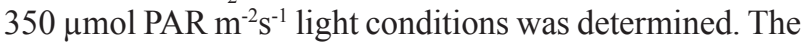
highest values were obtained in $D$. lutescens, which had been accustomed to high-light conditions before, under $350 \mu \mathrm{mol}$ PAR $\mathrm{m}^{-2} \mathrm{~s}^{-1}$. D. lutescens, having a leaf surface of $1 \mathrm{~m}^{2}$, reduced the $\mathrm{CO}_{2}$ amount in the environment by approximately $657 \mathrm{ppm}$ in one hour. The second highest value was obtained in $D$. deremensis (397 ppm) under the same conditions.

The results of the present study indicate that plants can considerably decrease the $\mathrm{CO}_{2}$ amount in the air, especially in light environments. Although plants are especially used for aesthetic and visual purposes, they affect the $\mathrm{CO}_{2}$ amount in the environment [2]. Previous research indicates that a beech tree with a leaf surface of $1,600 \mathrm{~m}^{2}$ can satisfy the oxygen need of 10 people [3-5, 16]. Torpy et al. [27] compared eight species. In the end, they revealed that if $D$. lutescens is used, which is the species having the highest reducing effect on $\mathrm{CO}_{2}, 249$ plants should be placed in an environment to balance the $\mathrm{CO}_{2}$ amount produced by a human being. Torpy et al. [27] stated that if $H$. forsteriana is used for the same purpose, 206 plants will be needed since $H$. forsteriana has a wider leaf surface. According to Pennisi and Iersel [28], approximately 400 plants will be needed if Spathiphyllum is used for the same purpose.

Although these results indicate that indoor plants do not have an adequate effect in reducing the $\mathrm{CO}_{2}$ amount in practice, two points should be noted. First, plants not only reduce indoor $\mathrm{CO}_{2}$ amount but also fulfill many 
other functions. Before anything else, plants reduce many pollutants such as nitrogen and sulfur oxides, carbon monoxide, volatile organic compounds, particles, ozone, $\mathrm{NO}_{2}$ (Nitrogen dioxide), formaldehydes, and heavy metals [6, 29]. Furthermore, indoor plants psychologically relieve people, reduce their stress and other negative feelings, and improve their productivity [3, $7,30]$.

\section{Conclusions}

The features sought in plants to be selected should be determined based on environmental conditions to ensure a more efficient use of plants. Research on this subject is inadequate for now. More research should be carried out on different plants; plants that photosynthesize faster in indoor conditions should be investigated; and different varieties, forms, and origins of the same species should be included in analyses.

The results of this study show that plants help reduce the $\mathrm{CO}_{2}$ amount in the light environment at different levels. Among the species used, Ficus is the plant that reduces the $\mathrm{CO}_{2}$ amount in the environment the fastest. Therefore, Ficus is the most suitable species to be used in reducing indoor $\mathrm{CO}_{2}$ amount, among the species included in the study. However, only four species were used in this study. If similar research is carried out on a variety of species, crucial information should be obtained with regard to which plants must be used to effectively reduce the $\mathrm{CO}_{2}$ amount in the environment.

Environmental conditions considerably influence speeds of photosynthesis of plants and thus their influence on $\mathrm{CO}_{2}$. Therefore, inclusion of factors such as temperature, light, plant size, and leaf structure in future research is important for determining which plants are more effective in specific environmental conditions.

\section{Acknowledgements}

This study is funded by the Scientific and Technological Research Council of Turkey (TUBITAK) with project No. 114Y033. We all thank TUBITAK for its support.

\section{References}

1. CETIN M. Determining the bioclimatic comfort in Kastamonu city. Environ. Monit. Assess. 187 (10), 640, 2015.

2. CETIN M. Using GIS analysis to assess urban green space in terms of accessibility: case study in Kutahya. Int. J. Sust. Dev. World. 22 (5), 420, 2015.

3. CETIN M. A Change in the Amount of $\mathrm{CO}_{2}$ at the Center of the Examination Halls: Case Study of Turkey. Studies on Ethno-Medicine, 10 (2), 146, 2016. Retrieved from http:// krepublishers.com/02-Journals/S-EM/EM-10-0-000-16Web/S-EM-10-2-16-Abst-PDF/S-EM-10-2-146-16-444Cetin-M/S-EM-10-2-146-16-444-Cetin-M-Tx[7].pdf
4. CETIN M. Evaluation of the sustainable tourism potential of a protected area for landscape planning: a case study of the ancient city of Pompeipolis in Kastamonu. Int. J. Sust. Dev. World. 22 (6), 490, 2015 doi: 10.1080/13504509.2015.1081651, 2015.

5. CETIN M., SEVIK H. Measuring the Impact of Selected Plants on Indoor $\mathrm{CO}_{2}$ Concentrations. Pol J Environ Stud. 25 (3), 973, 2016.

6. TANI A., HEWITT C.N. Uptake of aldehydes \& ketones at typical indoor concentrations by houseplants, Environ Sci Technol. 43 (21) 8338. 2009.

7. DJUKANOVIC R., WARGOCKI P., FANGER P.O. Costbenefit analysis of improved air quality in an office building, Proceedings: Indoor Air, 808. 2002.

8. FJELD T. The effect of interior planting on health and discomfort among workers and school children, HortTechnology, 10 (1), 46, 2000.

9. BULGURCU H., ILTEN N., COSGUN A. Indoor air quality problems and solutions in schools. Journal of Installation Engineering. 96, 59, 2006 [In Turkish].

10. CETIN M., SEVIK H. Change of air quality in Kastamonu city in terms of particulate matter and $\mathrm{CO}_{2}$ amount. Oxidation Communications. 39 (4-II), 3394, 2016.

11. CETIN M., SEVIK H., ISINKARALAR K. Changes in the particulate matter and $\mathrm{CO} 2$ concentrations based on the time and weather conditions: the case of Kastamonu, Oxidation Communications, 40 (1-II), 477, 2017.

12. TWARDELLAD., MATZEN W., LAHRZT., BURGHARDT R., SPEGEL H., HENDROWARSITO L., FRENZEL AC., FROMME H. Effect of classroom air quality on students' concentration: results of a cluster-randomized cross-over experimental study. Indoor Air 22 (5), 378. 2012

13. MUSCATIELLO N., MCCARTHY A., KIELB C., HSU W.H., HWANG S.A., LIN S. Classroom conditions and $\mathrm{CO} 2$ concentrations and teacher health symptom reporting in 10 New York State Schools. Indoor air, 25 (2), $157,2015$.

14. APTE M.G., FISK W.J., DAISEY J.M. Indoor carbon dioxide concentrations and SBS in office workers. In Proceedings of Healthy Buildings, 1, 133, 2000

15. KACAR B., KATKAT V., OZTURK S. Light, plant physiology. The Nobel Broadcast Distribution, Ankara, 270, 2010 [In Turkish]

16. SEVIK H., CETIN M., ISINKARALAR K. Effects of some indoor ornamental plants on the amount of indoor Carbondioxide. Duzce University. The Journal of Science and Technology. 4 (2), 493, 2015 [In Turkish].

17. KACAR B., KATKAT V., ÖZTÜRK Ş. Plant Physiology (4. Edition). Ankara: Nobel Publication distribution 2010 [In Turkish].

18. KÖSE B. Light and temperature in viticulture and its importance, Turkish Journal of Agricultural Research, 2014 (1), 203, 2014 [In Turkish].

19. AKMAN Y., GÜNEY K. Plant biology botany. Ankara: Palme publishing 2005 [In Turkish].

20. LERMI A.G., PALTA Ş. Research on some plant characteristics of Medicagopolymorpha L. Bartin ecology, COMU Journal of Faculty of Agriculture., 2 (2), 141, 2014. [In Turkish].

21. MAUSETH J.D. Introduction to botanical plant biology (4. Edition). Ankara: Nobel publication distribution. 2012.

22. CETIN M. Determination of bioclimatic comfort areas in landscape planning: A case study of Cide Coastline. Turkish Journal of Agriculture-Food Science and Technology 4 (9), $800,2016$. 
23. CETIN M. Sustainability of urban coastal area management: A case study on Cide. Journal of Sustainable Forestry. 35 (7), 527.

24. SEVIK H., CETIN M., BELKAYALI N. Effects of Forests on Amounts of $\mathrm{CO}_{2}$ : Case Study of Kastamonu and Ilgaz Mountain National Parks, Pol J Environ Stud., 24 (1), 253, 2015.

25. TORPY F.R., IRGA P.J., MOLDOVAN D., TARRAN J., BURCHETT M.D. Characterisation and biostimulation of benzene biodegradation in the potting-mix of indoor plants, Journal of Applied Horticulture, 15 (1), 10, 2013.

26. IRGA P.J., TORPY F.R., BURCHETT M.D. Can hydroculture be used to enhance the performance of indoor plants for the removal of air pollutants? Atmos Environ. 77, $267,2013$.
27. TORPY F.R., IRGA P.J., BURCHETT M.D. Profiling indoor plants for the amelioration of high $\mathrm{CO}_{2}$ concentrations, Urban For Urban Gree. 13 (2), 227, 2014.

28. PENNISI S., VANDVANIERSEL M.W. Quantification of carbon assimilation of plants in simulated and in situ interiorscapes. HortScience, 47 (4), 468, 2012

29. AYDOGAN A., MONTOYA L.D. Formaldehyde removal by common indoor plant species and various, growing media, Atmos Environ. 45, 2675, 2011.

30. CETIN M. Changes in the amount of chlorophyll in some plants of landscape studies. Kastamonu University Journal of Forestry Faculty. 16 (1), 239, 2016. 